\title{
Review of the potential role of electrokinetics technology in tailings dewatering and minerals recovery
}

\author{
D Kalumba University of Cape Town, South Africa \\ ST Mudenge National University of Science and Technology, Zimbabwe
}

\begin{abstract}
Water is employed as a cost-effective media of transporting tailings; a mixture of ground waste ore, water and chemicals used in metal extraction processes. Tailings are conveyed in pipelines from the plant to the tailings dam. From the dam, the water should be recycled back to the processing plant but herein lies the challenge. The hydraulic conductivity of fine-grained tailings is very low such that instead of draining, the water tends to accumulate in the dam. Not only does this led to pore water pressure build up which undermines the dam's stability, but it also causes massive water losses by evaporation more so in arid regions.
\end{abstract}

Dewatering of tailings prior to disposal has emerged as a solution that can be used to conserve water by producing paste or thickened tailings. Thickened tailings have higher shear strength, lower volume and they reduce dam closure costs. Filtered tailings can also be used as underground backfill for mine cavities or transported with conveyor belts and trucks to a designated point. The main limitation is that the benefits of dewatering are mainly technical and they do not yield a direct financial return. Processes that increase mineral production are vital in mine operations. Apart from the residue of the targeted metal, most tailings contain base metals like copper, nickel and zinc. Some mines have already established systems to extract valuable minerals from tailings; these include DRDGold, Lonmin and Sibanye mines in South Africa. Dewatering systems are designed to be in close contact with tailings and if they can perform the dual function of recovering water while extracting metals, they would fully meet the demands of the mining industry.

One of the most efficient techniques which can harness both dewatering and metal extraction is electrokinetics. Electrokinetics involves the application of an electrical current to induce the flow of water from the anode to the cathode in a process called electroosmosis. Electrokinetics also induces the migration of ions in a phenomenon termed electro migration. The metal cations precipitate at the cathode where they are collected and dried. This paper evaluates the viability of using an electrokinetic system to dewater and extract metals from tailings. Introducing a mineral extracting function could well be the key to increase the usage of tailings dewatering techniques by mines.

Keywords: tailings, dewatering, metal extraction, electrokinetics, electroosmosis, electro migration

\section{$1 \quad$ Introduction}

Mines use large quantities of water for their processes and as a result, tailings are generally discharged with high water volumes. Tailings deposition methods like spiggoting and cycloning aim to separate the coarse tailings from the fine. The coarse tailings are deposited on the dam wall because they are more permeable and this improves consolidation and reduces seepage forces in the dam wall. Fine tailings are purposefully discharged on the dam's beach where the dam water is also retained. World over, environmental regulations dictate that mines should practice conservation practices by recycling the water. The presence of water in a tailings dam can undermine its stability. Effects of pore water pressure on the dam's performance include reduced shear strength and high susceptibility to liquefaction (Smith \& Connell 1979).

Apart from having instability problems, tailings dams may also be a potential environmental hazard. If not handled properly they can cause land and water contamination because of their toxic chemical content. They 
may also emit dust which pollutes the air. Tailings dams occupy vast lands which could have been used for productive purposes and they distort the natural aesthetics of their environments. The closure of tailings dams can be a costly procedure if intensive dewatering is required for the cover system to be constructed. Due to these challenges, technologies that dewater tailings prior to disposal are gaining more recognition.

Dewatered tailings are also referred to as paste or thickened tailings. A paste is a solid-liquid mixture which produces little or no bleed water on deposition. Thickened tailings have higher initial consolidation due to less water content. Tailings paste can also be used as underground backfill material to support openings which are caused by mining (Saw \& Villaescusa 2013). They minimise mine subsidence and can function as a load-bearing mechanism to allow for pillar recovery. Paste and thickened tailings technology has been successfully implemented in various places such as Kimberly diamond mine in South Africa. Due to the low volumes and high shear strength of the dewatered tailings, the option of discarding the tailings without necessarily constructing a conventional tailings dam has been considered (Jones et al. 2008). In addition to recovering water, mines can also recover metals from tailings.

DRDGold was one of the first mines in South Africa to abandon underground mining and focus on tailings mining. The gold tailings reserve has a potential of giving the mine an $82 \%$ boost (Solomonds 2018). The tailings currently yield $120 \mathrm{~kg}$ or 3,800 oz of gold per month. Tailings associated with cassiterite deposits (a source of tin) contain rare earth metals (REM) (Szamalek et al. 2013). REM are used to manufacture electronic goods like televisions, cameras, mobile phones, computers, batteries and wind turbines. REM are highly sought after. Previously, REM could only be found in China but since cassiterite tailings have been identified as a potential source this will improve the availability of the metals and possibly reduce their price. Tailings can also contain high concentrations of base metals like copper, lead, nickel and zinc (Falagan et al. 2017). Base metals are used to manufacture glass, ceramics, coating and glazers, among other construction materials.

Due to the high demand for metals, there is a need for technologies that can be used to economically extract minerals from tailings. In electrokinetics the same principles that are used to recover metals from tailings can be used to recover water. Tailings dewatering systems have not successfully gained the attention of the mining industry because of the associated costs. Technologies that can couple dewatering and mineral extraction are likely to gain more recognition. Dewatering technologies ought to have a function that increases mineral productivity to avoid becoming an additional operating cost to the mine.

\section{$2 \quad$ Tailings dewatering techniques}

There are several methods which can be used to thicken tailings prior to their disposal. Table 1 makes a comparison of solids concentration between conventional and thickened tailings. The concentrations shown are mean values from several case studies. The solids content in thickened tailings depends on the particle distribution and shape, mineralogy and dewatering method used. From the table it can be observed that significant increases in solids content can be achieved from dewatering gold, base metals and bauxite but the thickening of mineral sands is marginal. Pre-trial tests are necessary to determine the suitability of using a given method for dewatering specific tailings. The test results should provide information on the optimum parameters for the process like $\mathrm{pH}$, temperature, duration, salinity, dosage and other design parameters.

Table 1 Comparison of solids concentrations in conventional and thickened tailings (after Williams \& Williams 2004)

\begin{tabular}{lll}
\hline Tailings type & $\begin{array}{l}\text { Concentration of weight of solids } \\
\text { in conventional tailings (\%) }\end{array}$ & $\begin{array}{l}\text { Concentration of weight of } \\
\text { solids in thickened tailings (\%) }\end{array}$ \\
\hline Base metal & 40 & 75 \\
Gold & 45 & 72 \\
Nickel & 35 & 45 \\
Bauxite & 25 & 45 \\
Mineral sands & 15 & 24 \\
\hline
\end{tabular}


The techniques commonly used to dewater tailings are explained in more detail in the following subsections.

\subsection{High rate thickener}

A high rate thickener is a tank which separates liquids from solids by exploiting their differences in density and settling velocity. It consists of rotating rake arms, a feed pipe, an overflow and an underflow outlet. The tailings slurry is delivered through the feedpipe. Thereafter, environmentally safe polymers are added to bind and settle the solids. The rotating rake arms move the settled sludge towards the underflow where it is discharged. The clarified water is channelled through the overflow and recycled back to the plant. There are different types of high rate thickeners which are manufactured to meet the varying demands of the mining industry. These include the deep cone, tilted plate and hydraulic motor driving centre thickener (Xinhai Mineral Processing 2019). The deep cone thickener has a large cone angle which increases the underflow concentration by up to 70\%. The tilted plate thickener has a tilted plate in the sedimentation area which reduces the tank height. The reduced tank height improves the system performance by 2-3 times. The hydraulic motor driving centre thickener has a central hydraulic and electric system which automatically controls the rake speed so as to achieve high solid concentrations. Advantages of using high rate thickeners include low energy consumption, high efficiency and low operation and maintenance costs. Figure 1 illustrates a typical high rate thickener.

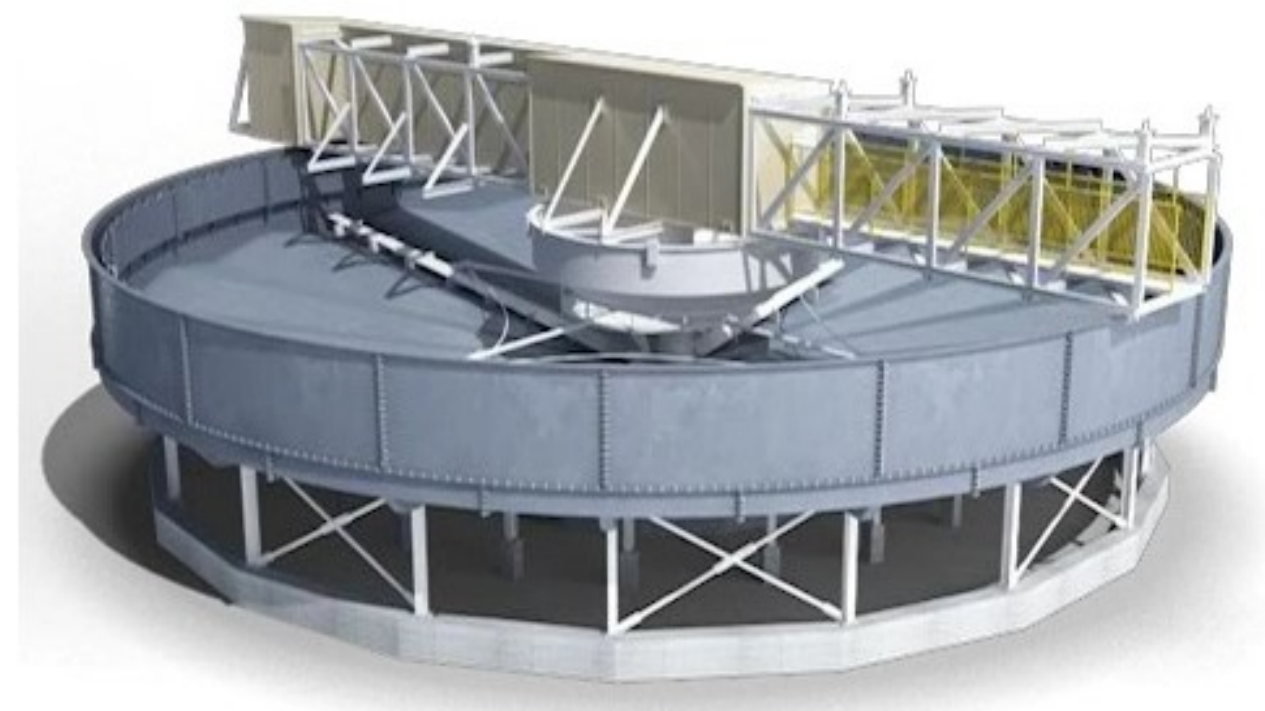

Figure 1 High rate thickener (Mining Life 2013)

\subsection{Filter press}

A filter press is a machine that expels water from a slurry by applying pressure. It mainly consists of a frame, filter plates, manifold and filter cloths. The frame acts as the filter plate holder. The filter plates are used to squeeze the sludge. The plates are covered with a filter cloth which is the surface on which the filter cake is formed. The manifold is a network of pipes, valves and filtrate discharge ports. When the slurry is pumped into the filter press, the filter cloth forms a cake layer by trapping the solids but allowing the liquids to flow through it. The filter cake will continue to build with increase in pressure. The fill cycle is completed when the chambers are filled. At this point the pressure applied on the plates is released to allow the plates to separate and the filter cake to fall by gravity. The expelled water or filtrate is collected by the filtrate ports and discharged through a single filtrate outlet. Filter presses vary in size from small machines for minor operations to heavy machines which handle large volumes of sludge. The choice of a filter press is a function of the tailings volumes to be handled and the physio-chemical properties of the tailings. Figure 2 illustrates a filter press machine. 


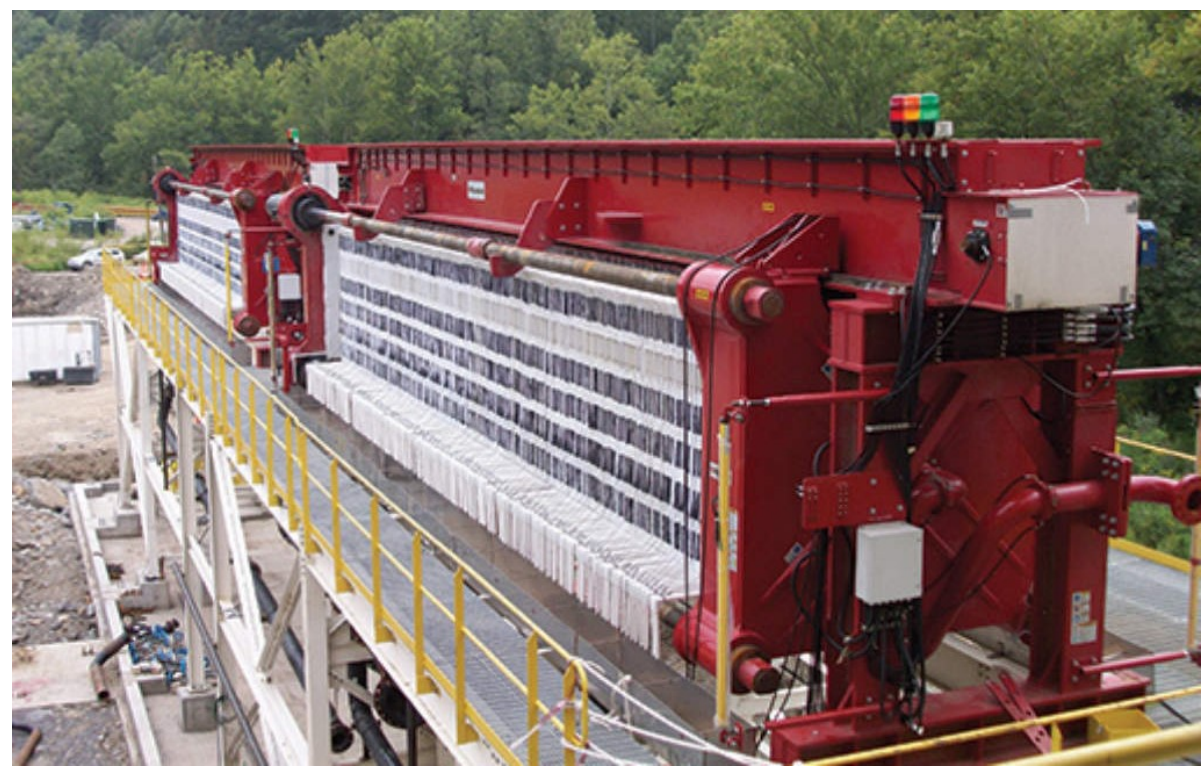

Figure 2 Filter press (McLanahan 2019)

\subsection{Decanter centrifuge}

A decanter centrifuge uses high rotational speed to separate components according to their density (Alfa Laval 2018). In tailings management, it is used to separate solids from liquids. The process involves pumping the tailings into the decanter where they are collected in a rotating bowl. The dense solids collect on the bowl walls and are settled out via an opening. The filtered water is discharged through a separate outlet. The decanter has an in-built gearbox which can be adjusted for different rotation speeds. Advantages of using a decanter centrifuge are that it is portable, fairly easy to use and requires a small working area. The typical long section of a decanter centrifuge is portrayed in Figure 3.

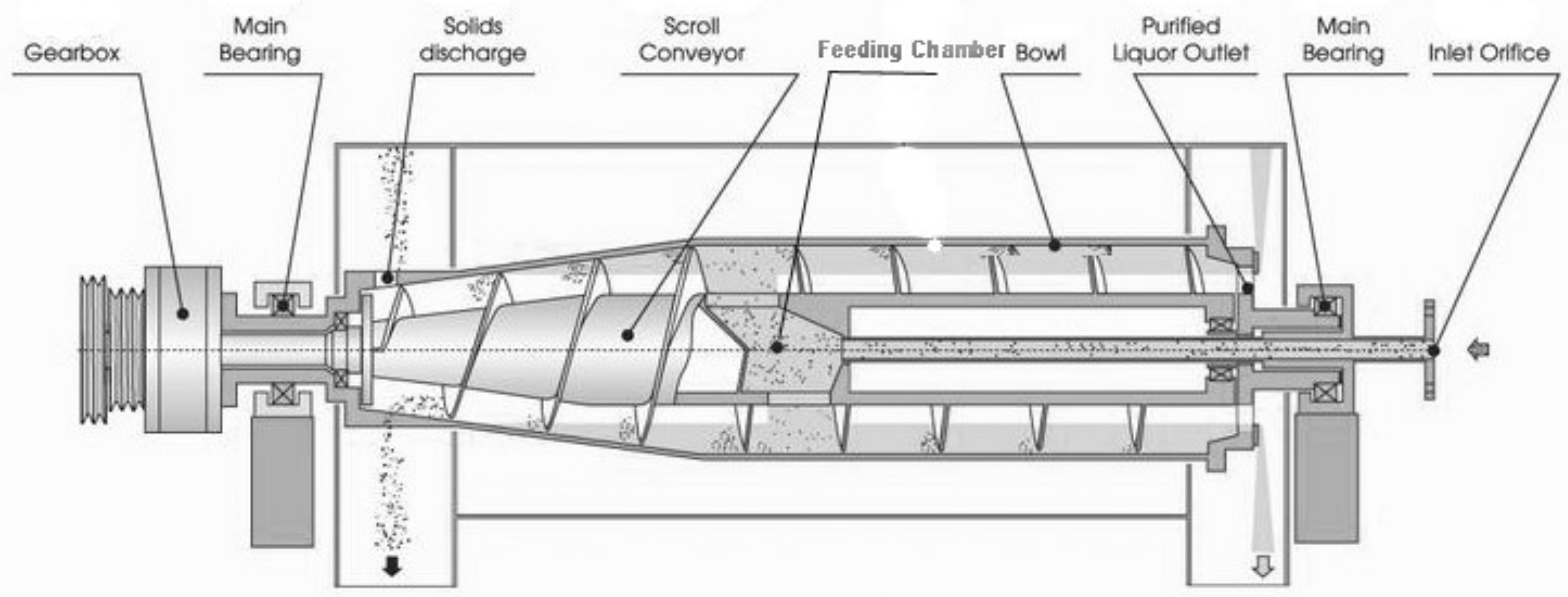

Figure 3 Decanter centrifuge - long section (GNSolidsControl 2018)

\subsection{Geosynthetic tube}

Geosynthetic tubes or geotubes are containers which can be used to recover both metals and water. The tailings are pumped into the geotube and then polymers are added to bind the solids and separate them from water. The clear filtered water drains through the tubes, is collected and recirculated. The dewatered tailings can be stored in the geotube containers which controls dust emissions and also eliminates erosion due to wind and water. Geotubes can achieve a volume reduction of up to $50 \%$. Geotubes can also be used to recover metals from tailings through heap leaching. The process involves placing the tailings-filled geotube on a lined heap leach pad with a drainage channel. A lixiviant solution is then applied to dissolve the metals 
from the tailings. The leachate is collected and the metals are recovered through a series of further chemical reactions. Figure 4 depicts sludge that was dewatered by a geotube.

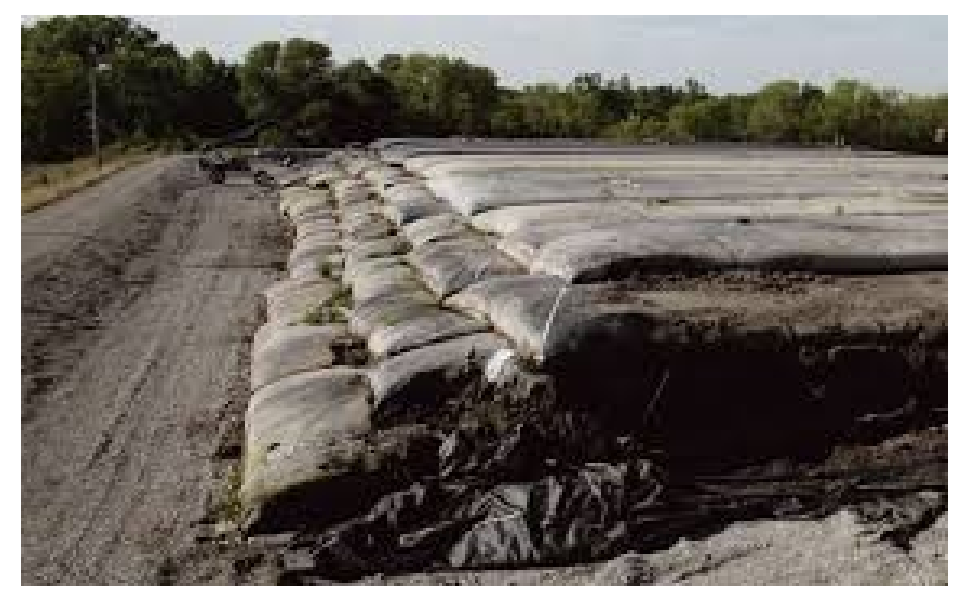

Figure 4 Geotube dewatered sludge (TenCate 2019)

\section{$2.5 \quad$ Electrokinetics}

Under suitable conditions, electrokinetics results in the movement of water from the anode to the cathode due to the influence of an electrical current. Early applications of electrokinetics in tailings management included dewatering of coal tailings (Lockhart 1986). Relatively inexpensive materials were used as electrodes like aluminium, copper and steel. The greatest impediment was the rapid corrosion of anode materials which needed constant replacement (Kalumba \& Glendinning 2006a). Corrosion resistant alternatives have been developed. These include the use of stainless steel, coating the electrodes with titanium, electrical vertical drains or use of electrokinetic geosynthetics (EKGs). Although stainless steel electrodes are durable, they are costly more so for large scale tailings dewatering applications. Electrical vertical drains consume high levels of voltage which also has cost implications (Chew et al. 2004). Titanium covered electrodes require recoating on a regular basis and this can be cumbersome for long-term projects. EKGs are more economic, durable and have greater electrical contact with tailings compared to other electrodes (Kalumba et al. 2009).

Electrokinetics is also used in filter bags and belt filter press equipment for dewatering. Filter bag material consists of conducting elements which become the system's cathode. They also have a central anode to complete the electrocell. Electrokinetic filter bags are used when the tailings volumes are moderate. For large tailings volumes the electrokinetic belt filter press is more appropriate. Typically, the upper belt is formed as the anode while the lower is the cathode through which the water is filtered away as shown in Figure 5 . The belts enclose a series of drums and rollers which squeeze the tailings to expel the water (Lamont-Black et al. 2007). Dewatering with the electrokinetic belt filter press combines both electroosmosis and pressure; two processes which result in a cake discharge with high solid content.

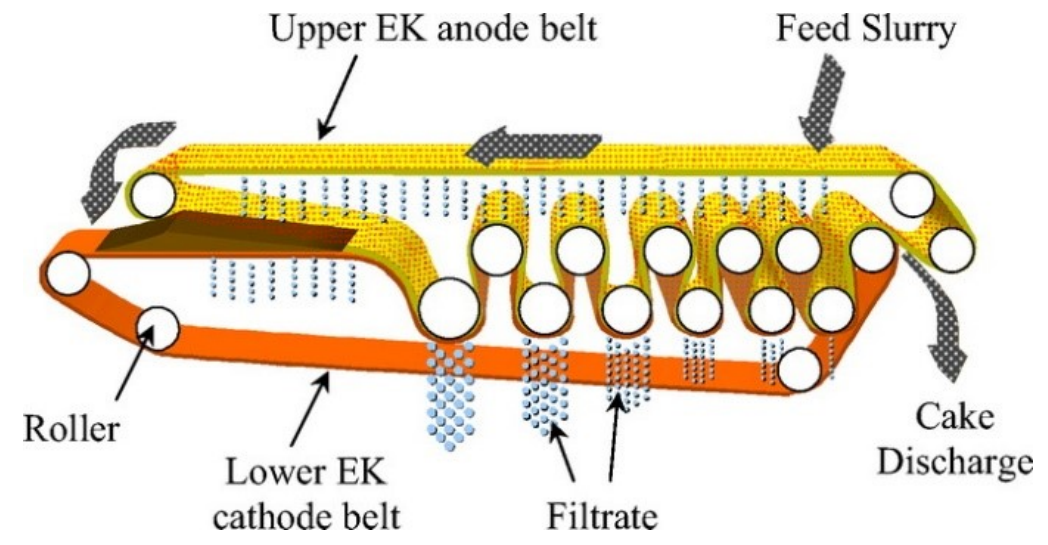

Figure 5 Electrokinetic belt press (Kalumba et al. 2009) 


\section{$3 \quad$ Metal extraction methods}

Tailings are not entirely composed of waste material but rather they are potential mineral reserves. Some of the techniques used to recover metals from tailings are described in the following sections.

\subsection{Washing}

The tailings are washed with metal absorbing thickeners and the metals are then removed from the thickener overflow (Adams \& Lloyd 2008). Thickeners are applied at a high rate to ensure metal-tailings separation. The process also produces clear water which can be recycled. Advantages of soil washing include high metal recovery and short process duration compared to other methods. In gold mines, washing is also used to recover cyanide. Cyanide is the single most expensive input required for gold extraction and mines consume large quantities of it. If not handled properly, cyanide can contaminate the environment. It can be recovered together with other metals by washing. Recycling of cyanide reduces operating costs and minimises the risk of land and water pollution. Mobile washing plants are available. Their main advantage is that they can be easily transported around a mine on any given terrain (United States Environmental Protection Agency 1997). Overall, washing can be used to recover three elements; metals, chemicals and water. Figure 6 illustrates a mobile tailings washing plant.

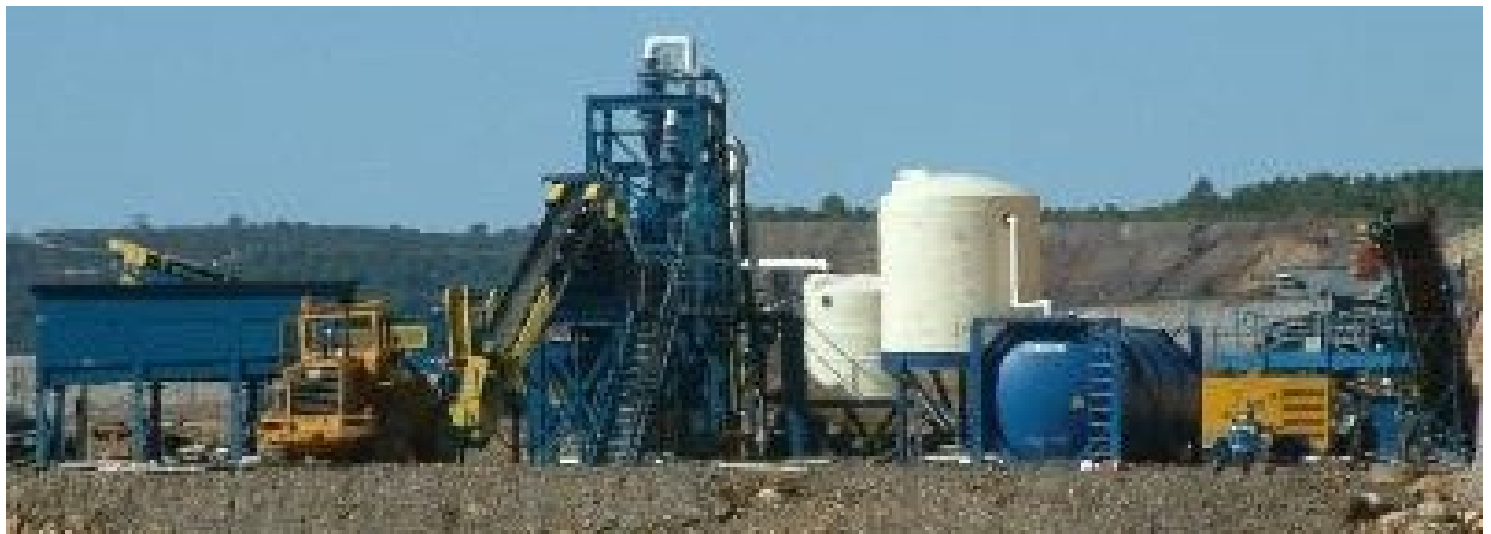

Figure 6 Mobile soil washing plant (ART Engineering 2018)

\subsection{Electro migration}

Electro migration or electrolysis is a technique which uses an electric field to recover metals. The tailings are first dissolved in an acidic or alkaline reagent and filtered (Fosso-Kankeu et al. 2015). The suitable reagent for the specific tailings can be determined from a series of tests or based on previous studies. An electric cell is then formed by introducing electrodes and applying a voltage to extract metals from the filtrate. The extracted metal forms a precipitate at the cathode, the precipitate is collected and dried at high temperatures. The composition can be assessed using an X-ray diffraction (XRD), an X-ray fluorescence (XRF) or a scanning electron microscope. Parameters that should be established from a laboratory pre-trial are the optimum voltage, duration for both the dissolution and electro migration stages and the reagent $\mathrm{pH}$ (Kalumba \& Glendinning 2006b). Electro migration was used to recover $99.9 \%$ tin with a lead cathode, a tin anode and hydrogen chloride electrolyte (Gergo et al. 2012). A laboratory experiment which used a tin anode, an iron cathode and hydrogen chloride electrolyte yielded a low $9 \%$ recovery (Jumari et al. 2018). The type of electrodes has a significant bearing on the amount of material recovered. Figure 7 shows the extraction of aluminium from aluminium oxide using graphite electrodes. 


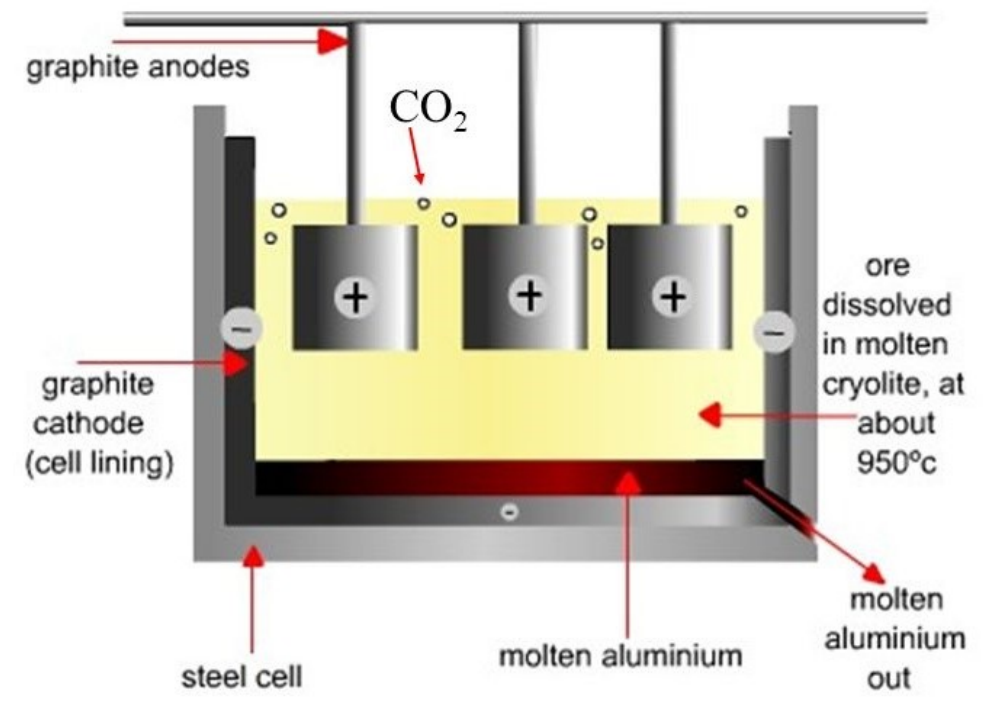

Figure 7 Electrolysis of aluminium oxide (Ibchem 2018)

\subsection{Chemical precipitation}

The process involves dosing the tailings with metal-absorbing chemical reagents like ligands surfactants, salts, acids and bases (Dermont et al. 2008). The metals precipitate into an insoluble salt which can be removed from the tailings by sedimentation or floatation. Recovery of metals by chemical precipitation depends on the properties of the chemical reagent, processing time, $\mathrm{pH}$, type and concentration of target metal. Chemical methods can be used to extract tailings from very fine tailings where other methods would not be applicable. Chemical precipitation should be implemented when the tailings geochemistry is well understood so that the appropriate reagent is used. Geochemistry includes several properties like particle size of tailings, capacity to exchange cations and buffering capacity. The major disadvantage of chemical methods is the high cost of chemicals. Also, the toxicity of the chemicals poses an environmental risk. Chemical precipitation can be used to extract REM from oil sand tailings as depicted in Figure 8.

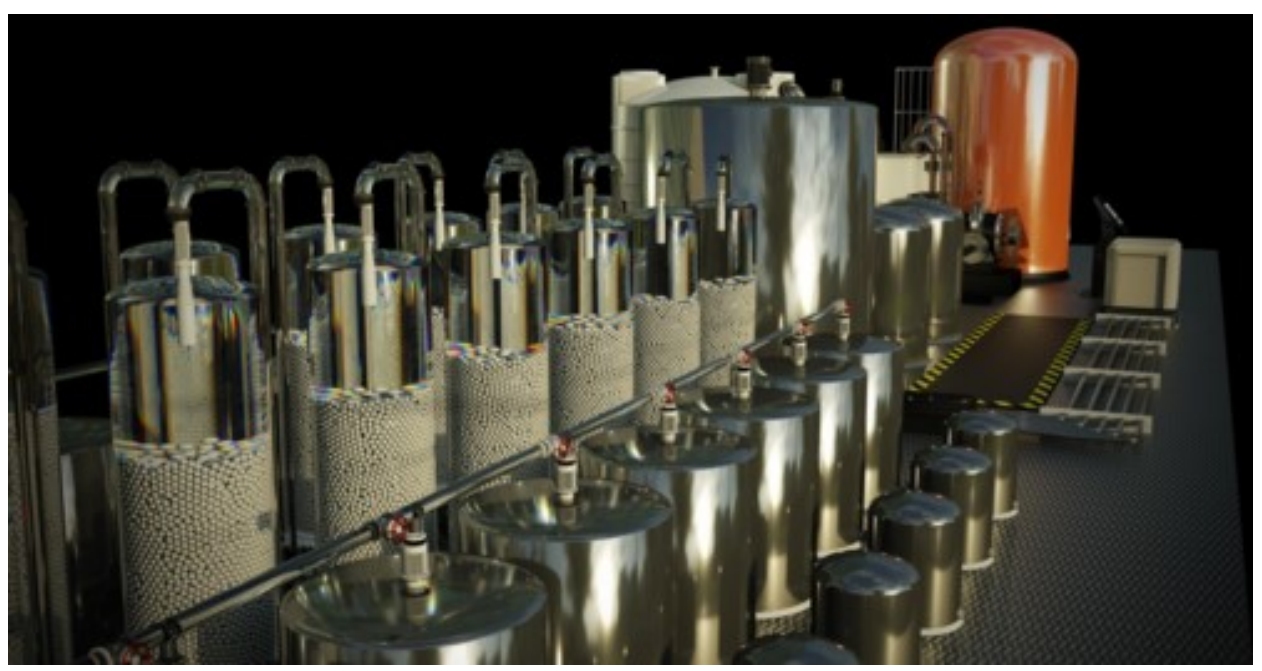

Figure 8 Chemical precipitation to recover rare earth metals from oil sands (Oil Sands Magazine 2017)

\subsection{Bioleaching}

Bioleaching is a technique which uses bacteria to oxidise sulphide minerals. Metal-absorbing bacteria include prokaryotic microorganisms, which are tolerant to acid (acidiphilic), metals (metaphilic) and temperature (thermophilic) (Dermont et al. 2008). Bioleaching can be performed under oxidative conditions, where prokaryotic microorganisms are used, or reductive conditions, where an extra metal is added to donate 
electrons to the microorganisms. This versatility makes the system applicable to a wide range of metals. Bioleaching was used to extract copper from tailings in Spain and Serbia as illustrated in Figure 9. The highest recovery rate was $84-90 \%$ at a temperature of $45^{\circ} \mathrm{C}$ and an acidic $\mathrm{pH}$ of 1 (Falagan et al. 2017).

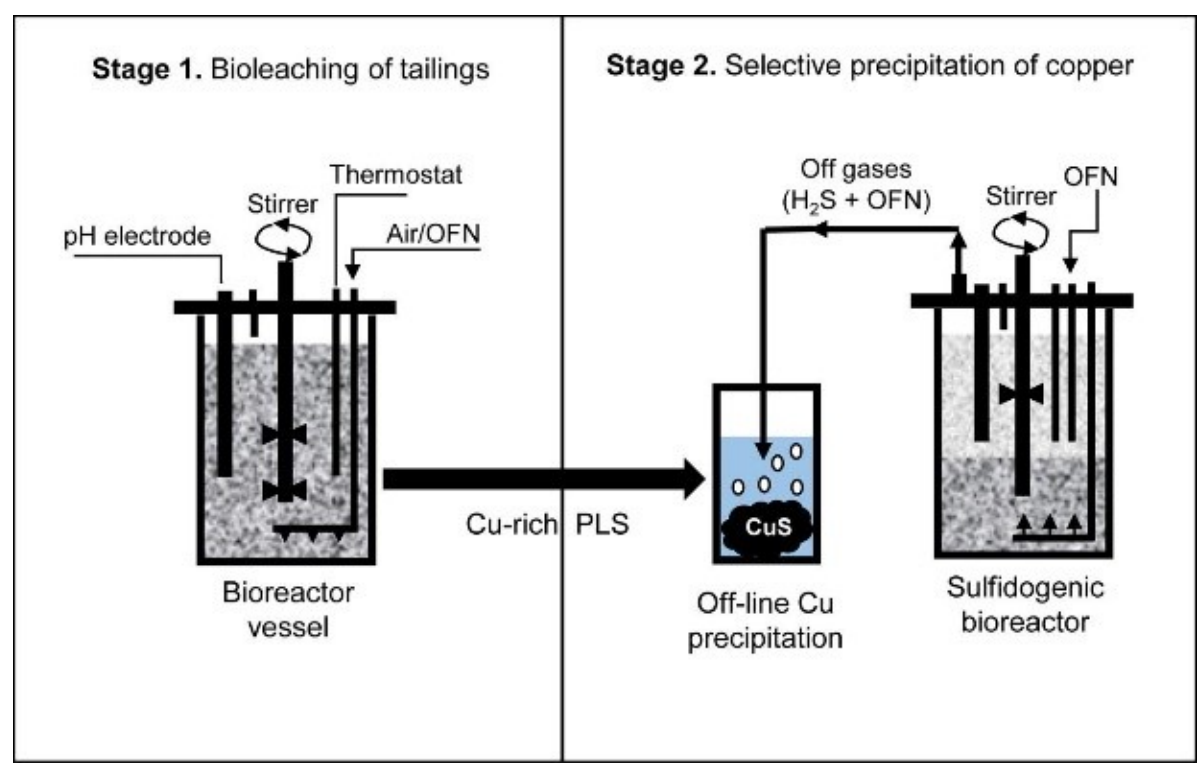

Figure 9 Bioleaching to recover copper from tailings (Falagan et al. 2017)

\subsection{Physical methods}

Physical methods separate metals from tailings based on their physical attributes like particle size, settling velocity, density, hydrophobic properties, electrical conductivity and magnetic properties. Compared to other techniques, physical methods are considered to be the most economical and easiest to implement. The mineralogy of the tailings should be known in order to select the appropriate method (Kalumba \& Glendinning 2006b). The method works well when the density of the target metal is significantly different from that of the tailings. Physical methods cannot be used when the metals are chemically embedded into the tailings or when the tailings have a high fines content. They are appropriate for tailings with at least $50-70 \%$ coarse aggregates. Table 2 outlines the most commonly used physical methods in metal extraction.

Table 2 Physical separation methods (after Dermont et al. 2008)

\begin{tabular}{|c|c|c|}
\hline Method & Principle & Process \\
\hline Attrition scrubbing & $\begin{array}{l}\text { Mechanical particle-particle } \\
\text { scrubbing }\end{array}$ & $\begin{array}{l}\text { Uses high energy agitation of tailings to } \\
\text { remove coating of particle surface and to } \\
\text { disperse tailings }\end{array}$ \\
\hline $\begin{array}{l}\text { Electrostatic } \\
\text { separation }\end{array}$ & $\begin{array}{l}\text { The electrical conductivity of } \\
\text { particles are different }\end{array}$ & $\begin{array}{l}\text { Metals are extracted based on their unique } \\
\text { electrical conductivity }\end{array}$ \\
\hline Froth floatation & $\begin{array}{l}\text { The hydrophobic properties of } \\
\text { metals and tailings are different }\end{array}$ & $\begin{array}{l}\text { Minerals are attached to air bubbles } \\
\text { injected in a pulp }\end{array}$ \\
\hline $\begin{array}{l}\text { Gravity } \\
\text { concentration }\end{array}$ & $\begin{array}{l}\text { Metals and tailings have } \\
\text { different densities }\end{array}$ & $\begin{array}{l}\text { Separates metals from tailings using their } \\
\text { density differences }\end{array}$ \\
\hline $\begin{array}{l}\text { Hydrodynamic } \\
\text { classification }\end{array}$ & $\begin{array}{l}\text { Particles have different settling } \\
\text { velocities }\end{array}$ & $\begin{array}{l}\text { Metals are recovered by applying a } \\
\text { centrifugal force into water flow }\end{array}$ \\
\hline $\begin{array}{l}\text { Magnetic } \\
\text { separation }\end{array}$ & $\begin{array}{l}\text { Metals and tailings do not have } \\
\text { the same magnetic properties }\end{array}$ & Metals are extracted using a magnetic force \\
\hline $\begin{array}{l}\text { Mechanical } \\
\text { screening }\end{array}$ & $\begin{array}{l}\text { Metals have different particle } \\
\text { sizes from tailings }\end{array}$ & $\begin{array}{l}\text { Extraction by size differences using a screen } \\
\text { barrier }\end{array}$ \\
\hline
\end{tabular}




\section{Application of electrokinetics in dewatering and extraction of metals from tailings}

\subsection{Theory of electrokinetics}

The preceding discussions have highlighted the use of electrokinetics in both dewatering and mineral extraction. One of the earliest electrokinetics experiments was conducted by Reuss (1809). The apparatus consisted of a U-tube, ground quartz, water and an electricity supply (Horwitz 1939). The powdered quartz, which represented a soil media with voids, was placed at the bottom of the tube. Under the influence of an electric current, the water moved from the anode to the U-tube arm representing the cathode as shown in Figure 10. Electrokinetics exploits the electrical conductivity of particles, liquids and ions. When an electric current is applied in a soil containing fluids, it activates four main processes namely; electro migration, electrophoresis, electrokinetic hardening and electroosmosis (White et al. 2008). Each of these processes has its own unique effect on the soil-fluid composition. Electro migration describes the movement of ions. Most metal ions are positively charged cations, hence they move towards the cathode. Electrophoresis is the movement of solids. Electrokinetic hardening results in stiffening of the tailings and this increases the shear strength of tailings impoundments. Electroosmosis is the flow of water in the tailings from the anode to the cathode. Water is oxidised at the anode which produces oxygen gas as demonstrated by Equation 1. It is reduced at the cathode which generates hydrogen gas as shown by Equation 2 .

$$
\begin{gathered}
\text { Anode: } 2 \mathrm{H}_{2} \mathrm{O}_{(l)}-4 e^{-} \Rightarrow \mathrm{O}_{2(g)}+4_{(a q)}^{+} \\
\text {Cathode: } 2 \mathrm{H}_{2} \mathrm{O}_{(l)}+2 e^{-} \Rightarrow H_{2(g)}+2 O H_{(a q)}^{-}
\end{gathered}
$$

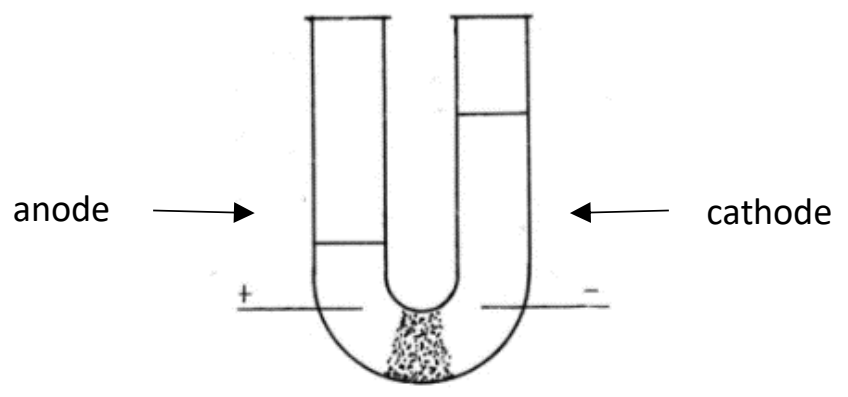

Figure 10 Ruess' electrokinetic U-tube (Horwitz 1939)

\subsection{Viability of dewatering tailings with electrokinetic}

Not all tailings can be dewatered using electrokinetics hence characterisation tests are needed to assess the feasibility thereof. The coefficient of electroosmotic permeability $\left(k_{\mathrm{e}}\right)$ and the electroosmotic coefficient of water transport $\left(\mathrm{k}_{\mathrm{i}}\right)$ are the two main parameters used to determine whether electrokinetic dewatering is possible. The electroosmotic permeability given by Equation 3 depends on a number of factors that include the tailings mineralogy, the void ratio, the applied voltage and current (Shang 1997).

$$
k_{e}=\frac{n \varepsilon_{w}}{\mu} \zeta
$$

where:

$$
\begin{array}{ll}
\mathrm{k}_{\mathrm{e}} & =\text { coefficient of electroosmotic permeability }\left(\mathrm{m}^{2} / \mathrm{sV}\right) \\
\mathrm{n} & =\text { porosity. } \\
\varepsilon_{w} & =\text { water permittivity }(\mathrm{F} / \mathrm{m}) . \\
\zeta & =\text { zeta potential }(\mathrm{V}) \\
\mu & =\operatorname{viscosity}\left(\mathrm{Ns} / \mathrm{m}^{2}\right) .
\end{array}
$$


These factors affect the electroosmotic permeability as follows:

- Porosity $(\mathrm{n})$ : The flow of water is a function of the voids in the tailings. Dewatering normally starts at a high rate but as the volume of voids decreases and the tailings compact the value of $k_{e}$ and the flow rate also decreases.

- Water permittivity $\left(\varepsilon_{w}\right)$ : It is the weakening of the electric field which is caused by an increase in salinity or hydraulic conductivity of the water.

- Zeta potential (Ъ): The zeta potential is a variable parameter which depends on the salinity of the water and its $\mathrm{pH}$. Tailings normally have a high negative zeta potential, and this is ideal because it indicates a high potential for flow. Increasing the pore water salinity reduces the zeta potential (Pugh 2002).

- Viscosity $(\mu)$ : The viscosity of tailings is very variable. Viscosity depends on the temperature and solid content.

The electroosmotic coefficient of water transport $k_{i}$ is expressed by Equation 4 as:

$$
k_{i}=\frac{k_{e}}{\lambda}
$$

where:

$$
\begin{aligned}
& k_{i} \quad=\text { electroosmotic coefficient of water transport }\left(\mathrm{m}^{3} / \mathrm{C}\right) . \\
& k_{\mathrm{e}} \quad=\text { coefficient of electroosmotic }\left(\mathrm{m}^{2} / \mathrm{sV}\right), \text { permeability. } \\
& \lambda \quad=\text { electrical conductivity of the soil }(\mathrm{S} / \mathrm{m}) .
\end{aligned}
$$

$\lambda$ is calculated using Equation 5:

$$
\lambda=\frac{L I}{A \Delta U}=\frac{J}{E}
$$

where:

$\mathrm{L} \quad=$ length between anode and cathode $(\mathrm{m})$.

I = electric current $(\mathrm{m})$.

A $=$ cross-sectional area $\left(\mathrm{m}^{2}\right)$ perpendicular to the direction of electric field.

$\Delta \mathrm{U}=$ electric potential drop across length $\mathrm{L}(\mathrm{V})$.

$\mathrm{E}=$ electric gradient $(\mathrm{V} / \mathrm{m})$.

$\mathrm{J}=$ current density applied on the soil $\left(\mathrm{A} / \mathrm{m}^{2}\right)$.

J can be computed using Equation 6:

$$
J=\frac{I}{A}
$$

The ratio $k_{e} / k_{i}$ increases with decrease of void ratio. A high $k_{e} / k_{i}$ ratio also increases the consolidation rate.

Electrokinetics dewatering should only be used if it can be proven that the electroosmotic flow $\left(Q_{e}\right)$ is greater than the hydraulic flow $\left(Q_{h}\right)$. $Q_{e}$ is given by Equation 7:

$$
Q_{e}=k_{e} \frac{V}{L} A
$$

where:

$$
\begin{aligned}
\mathrm{k}_{\mathrm{e}} & =\text { coefficient of electroosmotic permeability }\left(\mathrm{m}^{2} / \mathrm{sV}\right) \\
\frac{V}{L} & =\text { potential gradient }(\mathrm{V} / \mathrm{m}) \\
\mathrm{A} & =\operatorname{area}\left(\mathrm{m}^{2}\right) .
\end{aligned}
$$


The hydraulic flow $\left(Q_{h}\right)$ can be quantified using Darcy's Law expressed in Equation 8 as follows:

$$
Q_{h}=k i A
$$

where:

$$
\begin{aligned}
Q_{h} & =\text { hydraulic flow }\left(\mathrm{m}^{3} / \mathrm{s}\right) . \\
k & =\text { coefficient of permeability. } \\
\mathrm{i} & =\text { hydraulic gradient }(\mathrm{m} / \mathrm{s}) . \\
A & =\text { area }\left(\mathrm{m}^{2}\right) .
\end{aligned}
$$

The coefficients $k_{e}$ and $k_{i}$ can be measured using an electroosmotic test cell. The electroosmotic cell basically comprises of a cell, electrodes, load application device, electricity supply, water circulation system, monitoring and data gathering system. The electroosmosis test procedure begins by placing the tailings of known weight in the electroosmotic cell and measuring the height. A surcharge load is then applied to consolidate the tailings. With the electrodes in place the power supply is switched on and electroosmosis begins. The electroosmosis test can be conducted over the required period and the volume of water at the cathode measured at fixed time intervals. When the test is complete, other parameters that should be measured include the voltage gradient between the cathode and anode and within the soil mass. The final height and weight of tailings is measured and compared with the initial, leading to the calculation of the amount of water drained. The test can also be used to measure voltage losses which occur at the tailings-electrode interface (Shang 1997). Figure 11 illustrates a typical electroosmotic test cell.

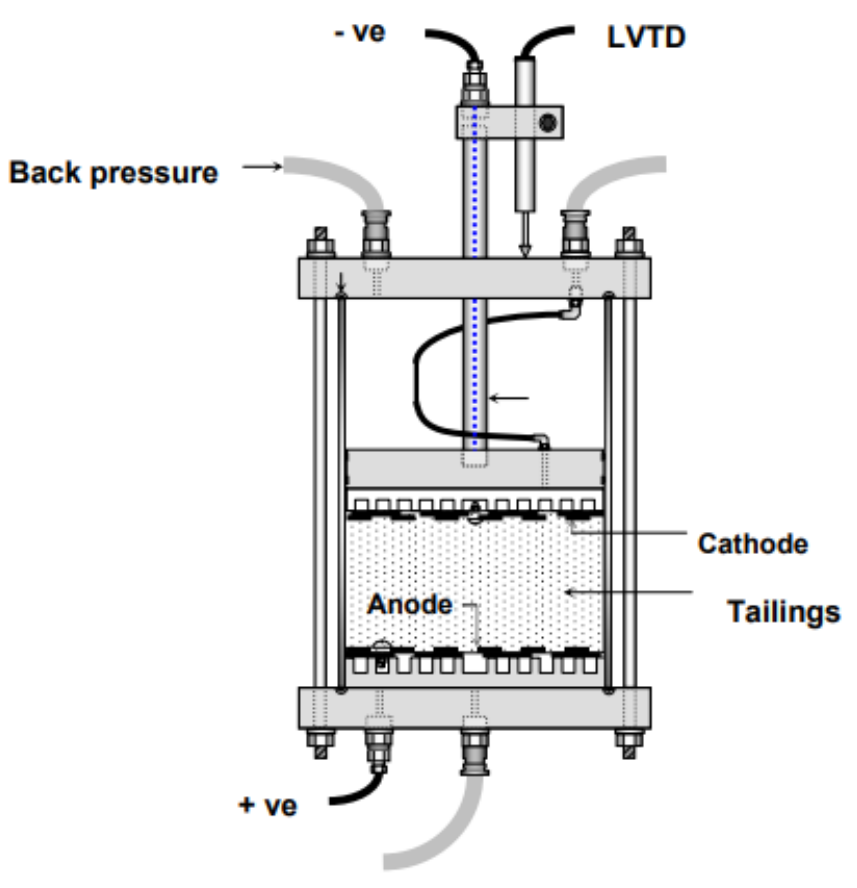

Figure 11 Electroosmotic test cell (Hamir 1997)

The hydraulic conductivity $\left(k_{h}\right)$ is another important parameter in dewatering applications because it influences the flow of water. Electrokinetics cannot be economically applied on tailings that have a high hydraulic conductivity because they demand higher voltage which in turn will escalate the project costs. Electroosmosis should only be used when the tailings hydraulic conductivity is in the range of $10^{-10}$ to $10^{-8} \mathrm{~m} / \mathrm{s}$ (Shang 1997). The hydraulic conductivity can be measured with a constant head test whereby water from a constant head reservoir flows upwards through the tailings under a low constant gradient (Qui \& Sego 2000). 
Electrokinetics accelerates the consolidation of tailings by creating negative pore pressure $(U)$ which can be determined using Equation 9:

$$
U=\left(k_{e} / k_{h}\right) \frac{V}{L}
$$

where:

$$
\begin{aligned}
& \mathrm{U}=\text { negative pore pressure }(\mathrm{kPa}) . \\
& \mathrm{k}_{\mathrm{e}} \quad=\text { coefficient of electroosmotic permeability }\left(\mathrm{m}^{2} / \mathrm{sV}\right) . \\
& \mathrm{k}_{\mathrm{h}} \quad=\text { hydraulic gradient }(\mathrm{m} / \mathrm{s}) . \\
& \mathrm{V} \quad=\text { electric potential drop across length } \mathrm{L}(\mathrm{V}) . \\
& \mathrm{L} \quad=\text { length between the electrodes }(\mathrm{m}) .
\end{aligned}
$$

A low $k_{h}$ value corresponds to a high value of $U$. The negative pore pressure increases the effective stress and hence the consolidation rate (Badv \& Mohammadzedeh 2015).

\subsection{Viability of extracting metals with electro migration}

Electro migration is an electrochemical process whereby an electrolytic cell is used to convert electrical energy to chemical energy. An electrolytic cell is not very different from the electroosmosis cell described in Section 4.2. It consists of an electrolyte and a positive anode electrode and a negative cathode electrode. The process involves breaking down the ionic substance into charged ions. Positive ions migrate to the cathode where a chemical reaction occurs that causes them to lose one or more electrons (Kalumba \& Glendinning 2006b). As a result, the positive ions become neutral atoms or molecules. The same process happens at the anode where negative ions gain electrons and either attain a higher charge or are converted into molecules. The main element in electro migration is the formation of metal molecules which can then be extracted from the cell.

Electrolysis can be used to extract a wide range of metals, but it is not recommended for all metal types. Metals that are more reactive than carbon in the reactivity series can be recovered using electrolysis. These mainly include aluminium, magnesium, calcium, sodium and potassium. Precious metals that can be recovered with electrolysis are gold, silver, platinum, palladium and rhodium, among others (Wiaux 1990). The mineralogy of tailings should be examined to assess the suitability of extracting with electrolysis. This can be achieved by an XRD or an XRF analysis. The mineral composition is also used to determine the appropriate electrolyte. The electrolyte should be able to dissolve the metal ions from the ore.

Metal extraction by electro migration is a two-stage process which begins with dissolution where the tailings are dissolved in a preheated acid or base solution (Jumari et al. 2018). The solution is then agitated at a predetermined speed to ensure complete dissolution. If the particles are large, they will require a longer time to dissolve, hence they consume more energy. The energy can be computed using Equation 10:

$$
E=\int \frac{V I}{1,000 \times 60} d t
$$

where:

$$
\begin{aligned}
\mathrm{E} & =\operatorname{energy}(\mathrm{KWh}) . \\
\mathrm{V} & =\operatorname{voltage}(\mathrm{V}) . \\
\mathrm{I} & =\operatorname{current}(\mathrm{A}) . \\
\mathrm{t} & =\operatorname{processing} \text { time }(\mathrm{h}) .
\end{aligned}
$$

A longer experiment demands more energy which would make the system uneconomic (Ntumba et al. 2014). For this reason, electrolysis is normally recommended for fine-grained tailings because they have a low dissolution period. 


\subsection{Considerations in the design of an electrokinetics system}

\subsubsection{Voltage requirements}

Low voltage gradients are more economical, but they slowdown the process. High voltages speed up the process but raise the water $\mathrm{pH}$ making it more corrosive to the electrodes (Veal et al. 2000). For optimum performance, the system can start with a high voltage which is then reduced gradually (Kalumba \& Glendinning 2006b; Lockhart 1983). The efficiency of using electrokinetics is governed by the power consumption $(P)$ which is defined as the energy required to treat one cubic meter of soil for a period of one hour (Guo 2012). P can be computed using Equation 11:

$$
P=\lambda E^{2}=j E
$$

where:

$$
\begin{aligned}
& \mathrm{P} \quad=\text { power consumption }\left(\mathrm{W} / \mathrm{m}^{3}\right) . \\
& \lambda \quad=\text { electrical conductivity of the soil }(\mathrm{S} / \mathrm{m}) . \\
& \mathrm{E} \quad=\text { electric gradient }(\mathrm{V} / \mathrm{m}) . \\
& \mathrm{j} \quad=\text { current density applied on the soil }\left(\mathrm{A} / \mathrm{m}^{2}\right) .
\end{aligned}
$$

The applied current should remain constant for optimum performance. A constant voltage reduces the current which in turn slows the system (Glendinning et al. 2010). When a constant current is applied, the flow rate is unaffected by material cross-sectional area and thickness.

\subsubsection{Management of collected water}

The water which collects at the cathode might recirculate and flow to the anode if not carefully managed. This backflow will also affect the tailings consolidation. There are two means which can be used to discharge the water; either by draining through the bottom or through a discharge well. A study by Yee \& Kaniraj (2010) demonstrated that the drainage well was the most effective of the two. Results of an electroosmotic test yielded 17 and $22 \%$ water reduction for the drainage bottom and drainage well respectively. The main reason for the higher efficiency is that in the drainage well setup, the distance between the electrodes is reduced hence the water is discharged more rapidly as shown in Figure 12.

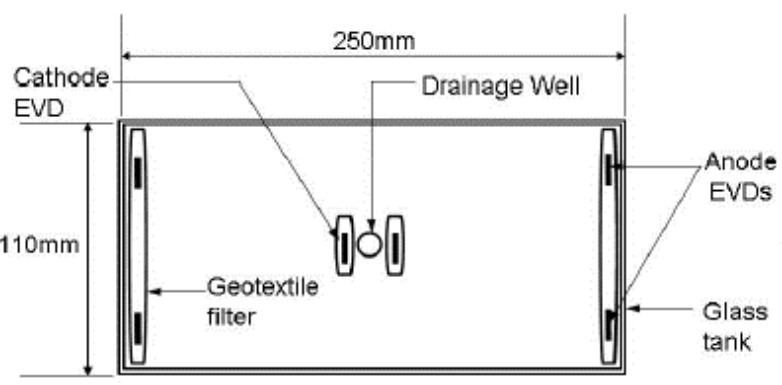

(a)

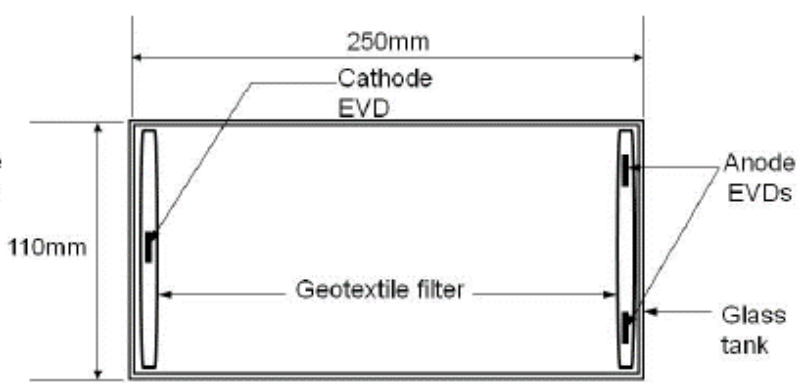

(b)

Figure 12 (a) Plan of tank with drainage well; (b) Plan of test with drainage at bottom (Yee \& Kaniraj 2010)

\subsubsection{Polarity reversal}

Polarity reversal occurs when an electrode which had been designed as an anode begins to serve as a cathode and vice versa causing the water or metal ions to flow in the reverse direction (Shang 1997). A suitable electrode should be able to continue to function when polarity reversal occurs. Without polarity reversal, the level of dewatering can be insignificant (Casagrande 1952). A key function of polarity reversal is that it can reverse differential settlement, thus improving the stability of tailings dams (Gray \& Somogyi 1977). Polarity reversal controls the $\mathrm{pH}$ which minimises corrosion of the electrodes. It also improves the hardening of tailings (Shang 1997). 


\subsubsection{Contact area of electrodes}

The contact area between tailings and electrodes should be maximised to ensure efficiency of system performance. Maximum contact can be achieved by using the highest possible number of electrodes. The oxygen and hydrogen gases which are produced at the anode and cathode electrodes respectively by the electrochemical reactions should be removed from the system. If left to accumulate, they can reduce the electrical contact between the electrodes and the tailings which would undermine the system's productivity (Jones et al. 2008).

\subsubsection{Optimum parameters}

Electro migration requires a series of tests to be conducted to determine the optimum parameters of the stirring speed, temperature and duration of dissolution and electrolysis. Generally, metal recovery has a linear relationship with the electrolysis duration. Dissolution increases with temperature and is more effective when the tailings have small particle sizes of less than $75 \mu \mathrm{m}$ (Ntumba et al. 2014). Electro migration reactions at the electrodes change the $\mathrm{pH}$ or solubility of the material but this can be avoided if the optimum conditions are used (Van Cauwenberghe 1997).

\section{Conclusion}

Due to the increasing demand for metals, mines currently produce higher tailings volumes than ever before. The fineness of tailings has also been increased by modern mining equipment used for ore processing. It is becoming more difficult for fine-grained tailings to dewater naturally because of their very low permeability. Dewatering techniques which produce filtered and thickened tailings are a promising solution but their usage by mines is still very low. One of the ways which can be used to upsurge the implementation of tailings dewatering technologies is to incorporate a mineral recovery function. REMs, base metals, precious metals and residues of the target metals are some of the minerals which can be extracted from tailings. Technologies which can perform the dual function of extracting both water and minerals from tailings are crucial. This paper has examined the plausibility of using electrokinetics to recover the two elements. The fundamental configuration for both electroosmosis and electro migration is the application of a potential gradient between the electrodes which will either cause the water to flow (dewater) or ions to move (metal extraction). There is need for further research in this area so that the technology can be scaled up to a practical sized operation.

\section{References}

Adams, M \& Lloyd, V 2008, 'Cyanide recovery by tailings washing and stripping', Minerals Engineering, vol. 21, issue 6, pp. 501-508. Alfa Laval 2018, Tailings Management: Meet the Tailings Challenge with Alfa Laval's Decanter Centrifuges, viewed 11 October 2018, https://www.alfalaval.com/globalassets/documents/industries/mining-and-pigment/pep00212en-tailings-management.pdf ART Engineering, 2018, Mobile Soil Washing Plant, viewed 3 November 2018, https://www.art-engineering.com/soil_washing.html

Badv, K \& Mohammadzedeh, K 2015, 'Laboratory assessment of the electroosmotic consolidation technique for Urmia lake sediments', Transactions of Civil Engineering, vol. 39, no. C2, pp. 485-496.

Casagrande, L 1952, 'Electroosmotic stabilization of soils', Journal of the Boston Society of Civil Engineers, vol. 39, no 1, pp. $51-83$.

Chew, SH, Karunaratne, GP, Kuma, VM, Lim, LH, Toh, ML \& Hee, AM 2004, 'A field trial for soft clay consolidation using electrical vertical drains', Geotextiles and Geomembranes, vol. 22, pp. 17-35.

Dermont, G, Bergeron, M, Mercier, G \& Richer-Lafleche, M 2008, 'Soil washing for metal removal: a review of physical/chemical technologies and field applications', Journal of Hazardous Material, vol. 153, pp. 1-31.

Falagan, C, Grail, BM \& Johnson, B 2017, 'New approaches for extracting and recovering metals from mine tailings', Minerals Engineering, vol. 106, pp. 71-78.

Fosso-Kankeu, E, Waanders, F \& Botes, W 2015, 'Recovery of base metals from mine tailings dumps collected in the vicinity of Potchefstroom: leaching assisted by complexing agent', Proceedings of the Seventh International Conference on Latest Trends in Engineering and Technology, Institute of Electrical and Electronics Engineers, Piscataway, pp. 103-106.

Gergo, R, Kulscar, T \& Kekesi, T 2012, 'Application of $\mathrm{HCl}$ solution for recovering the high purity metal from tin scrap by electrorefining', Hydrometallurgy, vol. 125-126, pp. 55-63.

Glendinning, S, Mok, CK, Kalumba, D, Rogers, CDF \& Hunt, DVL 2010, 'Design framework for electro- kinetically enhanced dewatering of sludge', Journal of Environmental Engineering, vol. 136, pp. 417-426.

GN Solids Control 2018, Decanter Centrifuge, viewed 22 October 2018, http://www.gnsolidscontrol.com/decanting-centrifuge/ 
Gray, DH \& Somogyi, E 1977, 'Electro-osmotic dewatering with polarity reversals, Journal of Geotechnical Engineering, vol. 103, issue 1, pp. 51-54.

Guo, Y 2012, Electrokinetic Dewatering of Oil Sands Tailings, PhD thesis, The University of Western Ontario, Ontario.

Hamir, R 1997, Some Aspects and Applications of Electrically Conductive Geosynthetic Materials, PhD thesis, Newcastle University, Newcastle upon Tyne.

Horwitz, W 1939, 'The theory of electro-kinetic phenomena', Journal of Chemical Education, vol. 16, no. 11, pp. 519-535.

Ibchem 2018, Hall Cell, viewed 13 November 2018, https://ibchem.com/IB/ibnotes/full/ope_htm/hall_cell.htm

Jones, CJFP, Black-Lamont, J, Glendinning, S, Bergado, D, Eng, Fourie, AB, Liming, H, Pugh, C, Romantshuk, M, Simpanen, S \& Feng ZY 2008, 'Recent research and applications in the use of electro-kinetic geosynthetics', Proceedings of EuroGeo4: the Fourth European Geosynthetics Conference, International Geosynthetics Society, Jupiter.

Jumari, A, Purwanto, A, Nur,A, Badiman AW, Lerian, M \& Paramita, F 2018, 'Tin recovery from tin slag using electrolysis method', Proceedings of the 3rd International Conference on Industrial, Mechanical, Electrical, and Chemical Engineering, in A Nur, AT Wijayanta \& AW Budiman (eds), AIP Publishing LLC, Melville, pp. 030011-1-030011-5.

Kalumba, D \& Glendinning, S 2006a, 'A bench scale model for developing of an integrated in-situ remediation for heavy metals using EKG electrodes', in N Lu, LR Hoyos \& L Reddi (eds), Proceedings of GeoShanghai International Conference: Advances in Unsaturated Soil, Seepage, and Environmental Geotechnics, American Society of Civil Engineers, Reston, pp. 262-270.

Kalumba, D \& Glendinning, S 2006b, 'An integrated in-situ remediation technology or heavy metal contaminated soils using EKG', in HR Thomas (ed.), Proceedings of the Fifth International Congress on Environmental Geotechnics, vol. 1, International Society of Soil Mechanics and Geotechnical Engineering, London, pp. 180-187.

Kalumba, D, Glendinning, S, Rogers, CDF, Tryer, M \& Boardman, DI 2009, 'Dewatering of tunneling slurry wastes using electrokinetic geosynthetics', Journal of Environmental Engineering, vol. 135, pp. 1227-1236.

Lamont-Black, J, Jones, CJFP, Glendinning, S, Huntley, DT \& Fourie, AB 2007, 'Laboratory evaluation of the potential for electrokinetic belt filter press dewatering of kimberlite slimes', in AB Fourie \& RJ Jewell (eds), Proceedings of the Tenth International Conference on Paste and Thickened Tailings, Australian Centre for Geomechanics, Perth , pp. 147-152.

Lockhart, NC 1983, 'Electroosmotic dewatering of clays. I. Influence of voltage', Colloids and Surfaces, vol. 6, issue 3, pp. $229-238$.

Lockhart, NC 1986 'Electro-dewatering of fine suspensions', Advances in Solid-Liquid Separation, pp. 241-274.

McLanahan 2019, Filter Presses, viewed 11 January 2019, https://www.mclanahan.com/products/filter-press

Mining Life 2013, Featured Mining Project: Bolted 31m Thickener, viewed 10 January 2019, http://mininglifeonline.net/news_view_1350.html

Ntumba, E, Malenga, E, Nheta, W \& Mulaba-Bafubiandi, AF 2014, 'Kinetic studies of nickel dissolution from ammonium jarosite precipitate in an alkaline medium', Proceedings of the International Conference on Mining, Material and Metallurgical Engineering, International Academy of Science, Engineering and Technology, Prague, p. 114.

Oil Sands Magazine 2017, Generating Cash from Tailings: A "Green Chemistry" Approach to Extracting More Value from the Oil Sands, viewed 15 November 2018, https://www.oilsandsmagazine.com/news/2017/6/27/generating-cash-from-tailings-a-greentech-approach-to-extracting-more-value-from-the-oil-sands

Pugh, RC 2002, The Application of Electrokinetic Geosynthetics to uses in the Construction Industry, PhD thesis, Newcastle University, Newcastle upon Tyne.

Qui, YJ \& Sego, DC 2000,'Laboratory properties of mine tailings', Canadian Geotechnical Journal, vol. 38, pp. $183-190$.

Reuss, FF 1809, 'Sur un nouvel effet de l'électricité galvanique', Mémoires de la Societé Imperiale de Naturalistes de Moscou, vol. 2 , pp. 327-336.

Saw, H \& Villaescusa, E 2013, 'Geotechnical properties of mine fill', in CF Leung, SH Goh \& RF Shen (eds), Proceedings of the 18th Southeast Asian Geotechnical Conference: Advances in Geotechnical Infrastructure, Geotechnical Society of Singapore, Singapore, pp. 787-792.

Shang, JQ 1997, 'Zeta potential and electroosmotic permeability of clay soils', Canadian Geotechnical Journal, vol. 34, pp. 627-631.

Smith, ES \& Connell, DH 1979, The Role of Water in the Failure of Tailings Dams, viewed 5 October 2018, https://www.imwa.info/docs/imds_1979/IMDS1979_Smith_627.pdf

Solomonds, SL 2018, DRDGold: South Africa's largest tailings project kicks into first gear, viewed 20 December 2018 , https://www.miningreview.com/drdgold-largest-tailings/

Szamalek, K, Marciniak-Maliszewska B, Konopka G \& Zglinicki, K 2013, 'New potential source of rare earth elements', Gospodarka Surowcami Mineralnymi, vol. 29, no. 4, pp 59-76.

TenCate 2019, TenCate Dewatering System Brochure, viewed 10 January 2019, https://www.tencategeotube.com/en/technicalinfo/brochures

United States Environmental Protection Agency 1997, 'Technology alternatives for the remediation of soils contaminated with As, $\mathrm{Cd}, \mathrm{Cr}, \mathrm{Hg}$, and Pb', Engineering Bulletin, EPA/540/S-97/500, August 1997.

Van Cauwenberghe, L 1997, Electrokinetics Technology Overview Report, TO 97-03, Ground Remediation Technologies Analysis Centre, Pittsburgh.

Veal, C, Johnston, B \& Miller, S 2000, 'The electro-osmotic dewatering (EOD) of mine tailings', Proceedings of the Fourteenth Annual Conference of the American Filtration and Separations Society, American Filtration and Separations Society, Nashville, pp. 14-16.

White, C, Glendinning, S, Lamont-Black, J, Jones, CJFP \& Taylor, T 2008, 'The application of electrokinetic geosynthetics in the advanced conditioning and composting process of sewage sludge', Proceedings of EuroGeo4: the Fourth European Geosynthetics Conference, International Geosynthetics Society, Jupiter.

Wiaux, JP 1990, The Recovery and Recycling of Metals Using Electrolysis, ELTECH System Corp., Geneva. 
Williams, DA \& Williams, DJ 2004, 'Trends in tailings storage facility design and alternative disposal methods', Proceedings of the Australian Centre for Minerals Extension and Research Workshop on Design and Management of Tailings Storage Facilities to Minimise Environmental Impacts During Operation and Closure, Australian Centre for Minerals Extension and Research, Brisbane, p. 28.

Xinhai Mineral Processing 2019, High Rate Thickener, viewed 9 January 2019, https://m.xinhaimineral.com/equipment.html

Yee, S \& Kaniraj, R 2010, 'Performance of drainage well in electro-osmotic consolidation experiment', Proceedings of the Indian Geotechnical Conference, Macmillan Publishers India Ltd., New Delhi, pp. 503-506. 